\title{
Investigation of performance on forest products industry with performance appraisal system
}

\author{
Aytaç AYDIN ${ }^{1 *}$, Sebahattin TIRYAKI ${ }^{1}$ \\ ${ }^{1}$ Karadeniz Technical University, Faculty of Forestry, Trabzon, TURKEY \\ *Corresponding author: aytac@ktu.edu.tr
}

Received Date: 13.01.2017

Accepted Date: 26.05 .2017

\section{Abstract}

Aim of study: The purpose of this study is to determine whether there is or not a difference depending on the demographic characteristics of the participants and in the sub sectors level of performance appraisal practices with productivity and motivational effects of the performance appraisal systems applied in the businesses. The study was applied to 432 people that work in 14 businesses operating in forest products industry (furniture, panel products, paper and paper products) throughout Turkey.

Material and Methods: For this purpose, the questionnaire prepared was administered to employees in businesses with face to face interviews. The collected questionnaires were entered to SPSS (Statistical Package for the Social Sciences) and tested by descriptive statistics, factor analysis and analysis of variance.

Main results: When the results were analyzed, it was seen that performance appraisal practices may be divided into six factors (performance appraisal's aim, criteria, interviews, applications, productivity impact and motivational impact). It was also determined that the performance appraisal system subsectors do not show a difference in terms of sub-factors of the forest products industry. In addition, according to the results of variance analysis carried out based on demographics characteristics, it was not observed a significant difference in terms of age groups, while significant differences were identified at the level of performance appraisal sub-factors in terms of education status, gender, marital status, position and total operating time.

Research highlights: Performance appraisal studies are very important for businesses since they include indicators of employee productivity.

Keywords: Factor analysis, Forest products industry, Performance appraisal, Analysis of variance

\section{Performans değerlendirme sistemi ile orman ürünleri endüstrisinde performans araştırması}

\section{Özet}

Çalıșmanın amacı: Bu çalışma ile Türkiye genelinde orman ürünleri sanayi sektörlerinde (mobilya, levha ürünleri, kağıt ve kağıt ürünleri) yer alan 14 orman ürünleri işletmesinde çalışan 432 kişiye ulaşlarak işletmelerde uygulanan performans değerlendirme sistemlerinin verimlilik ve motivasyonel etkileri ile performans değerlendirme uygulamalarının alt sektörler düzeyinde ve katılımcıların demografik özelliklerine bağlı olarak farklılık gösterip göstermediği araştırılmıştır.

Materyal ve Yöntem: Bu amaçla hazırlanan anket formu, işletmelerdeki çalışanlara yüz yüze görüşme tekniği ile uygulanmıştır. Toplanan anketler, SPSS paket programına işlenerek açıklayıcı istatistikler, faktör analizi ve varyans analizi ile test edilmiştir.

Sonuçlar: Sonuçlar incelendiğinde, performans değerlendirme uygulamaların altı tane faktöre (performans değerlendirmenin; amacı, kriterleri, görüşmeleri, uygulamaları, verimlilik etkisi ve motivasyonel etkisi) ayrılabileceği belirlenmiştir. Performans değerlendirme sistemleri alt faktörleri bakımından orman ürünleri sanayi alt sektörleri bazında anlamlı bir farkın olmadığı belirlenmiştir. Ayrıca demografik özelliklere göre yapılan varyans analizi sonuçlarına göre yaş grupları bakımından anlamlı bir farklılık olmamakla beraber, eğitim durumu, cinsiyet, medeni durum, çalışılan pozisyon ve toplam çalışma süresine göre performans değerlendirme alt faktörleri düzeyinde anlamlı farklılıklar belirlenmiştir.

Araștırma vurguları: İșletmeler açısından performans değerlendirme çalışmaları çalışanların verimliliğine yönelik göstergeler içerdiğinden işletmeler için çok önemli uygulamalardır.

Anahtar kelimeler: Faktör analizi, Orman ürünleri sanayi, Performans değerlendirme, Varyans analizi 


\section{Introduction}

The success in the human factor that has to be considered from many aspects within production units can be achieved by analysis of the factors that will affect human' work and by ensuring the proper conditions for these factors. In this context, performing the required performance analysis, taking the assessments and taking performanceimproving measures are among indispensable events in today's world for businesses.

Performance Management System (PMS) is a system that helps organizations to achieve their organizational objectives (Chenhall, 2005; Ferreira \& Otley, 2009). In practice, although many performance management systems are available, their basic principles are largely similar to each other. Among them, the most important factors linking the strategic management systems with PMS are performance criteria that determine the vision and strategy of the organization (Pirttimäki et al., 2006).

The performance of employees may be described as performing their work within acceptable limits, as defined by the business managers. Appraisal of performance revealed by employees is very important in achieving the objectives in the workplace and in determining the contribution of the employees in achieving these goals. These assessments contribute to personal and organizational development in the workplace (Akçakanat, 2009).

Performance appraisal (PA) intends to evaluate the performance of employees as objectively as possible. It was reported that a well-designed PA system helps develop employee performance-related criteria, provides a feedback mechanism and enables a more equitable reward system. It was also stated that employees' productivity increases when a fair system is available for PA in any organizations. In this regard, PA undertakes a critical task for organizations in order to reach their strategic objectives (Kumbhar, 2011). According to Ataay (1990), PA helps business managers in taking important business decisions such as recruitment of new workers, supervision of employees at trial, making wage adjustments, training and development of employees, promotion and job change, dismissal and hiring. PA also allows the managers to make these decisions easier.

Forest products industry has important role in manufacturing industry. This sector has sub-sectors such as paper, timber, furniture, particle board (Serin et al., 2014). Furniture industry is a part of secondary manufacturing that is one of the six subsectors of forestry (Serin \& Şahin, 2016). Particle board is used in furniture, forestry enterprises, glue industry, timber factories, paper sector, construction, decoration, energy sector, and other fields (Şahin \& Serin, 2016).

The best way to compare the effectiveness of the performance management systems implemented in businesses is the examination of the systems from the point of view of employees (Dewettinck \& van Dijk, 2013; Mishra \& Farooqi, 2013). This study aims to be evaluated by the employees in terms of sub-sectors and some demographics properties of the performance appraisal systems located in performance management system in forest products industry.

\section{Materials and Methods}

The population of the study consists of forest products businesses operating in the forest products industry throughout Turkey. Identification of the study was made through reaching the businesses and they were informed about the procedure. 14 of these businesses have adopted the implementation of the study. Of the participant businesses, 7 operate in furniture, 6 operate wood based panel and 1 operates in paper production. As a result, a total of 432 assessable questionnaires were provided from these businesses.

A questionnaire prepared by benefiting from a previous PA study was used for in the present study (Tarlığ, 2006; Yılmaz, 2006). The questionnaire consists of 3 sections; the questions designed to determine the PA applications prepared in 5-point Likert-type, business information and personal information.

Completed questionnaires were entered into SPSS statistical software package, and then the frequency tables, reliability 
analyses, validity analyses and analysis of variances were performed.

\section{Results}

\section{Scale reliability and validity}

Although there are many models used in reliability analyses, Cronbach alpha coefficient was employed for the present study. According to the analysis results, it was determined that Cronbach alpha coefficient was 0.950 . This number varies between 0 and 1 , and values over 0.90 mean excellent agreement (Kalayc1, 2009).

Moreover, a factor analysis was made in order to measure structural validity of the study. However, before moving on to factor analysis, it is essential to test conformity of the data set with Kaiser-Meyer-Olkin (KMO) measure of sampling adequacy. KMO is an index that compares the magnitudes of observed correlations and partial correlations, and for validity, this rate should be over 0.5 (Sharma 1995). In this study, KMO value was found as 0.917 (Bartlett's

\section{Demographic characteristics}

Test of Sphericity Sig.:0.001), and it was decided that the study was appropriate for factor analysis.

Basic components analysis and varimax rotation technique were used in factor analysis procedure. As a result of the analysis, from 51 items, 18 items which are nonconforming or which load on more than one factor were discarded. The remaining 33 items formed 6 sub-factors with eigenvalues bigger than 1. Total expressiveness of this six- factored structure was $59.942 \%$. In the structure, the first factor was the purpose of PA with an expressiveness of $13.201 \%$, the second factor was the criteria of PA with an expressiveness of $11.258 \%$; the third factor was PA interviews with an expressiveness of $11.178 \%$; the fourth factor was the PA applications with an expressiveness of 9.555 $\%$; the fifth factor was the productivity effect of PA with an expressiveness of $7.991 \%$; the sixth factor was The motivation effect of PA with an expressiveness of $6.753 \%$

Some demographic characteristics of the participants are given in Table 1 .

Table 1: The findings belonging to demographic characteristics

\begin{tabular}{llrllr}
\hline Age & $\mathbf{n}$ & $\mathbf{\%}$ & Position & $\mathbf{n}$ & $\mathbf{\%}$ \\
\hline 19 and below & 7 & 1.6 & Senior & 38 & 8.8 \\
$20-24$ & 46 & 10.6 & Middle-level & 175 & 40.5 \\
$25-29$ & 103 & 23.8 & Employee & 189 & 43.8 \\
$30-34$ & 111 & 25.7 & Unanswered & 30 & 6.9 \\
$35-39$ & 93 & 21.5 & Total & $\mathbf{4 3 2}$ & $\mathbf{1 0 0}$ \\
\cline { 5 - 6 } $50-49$ & 67 & 15.5 & Educational status & $\mathbf{n}$ & $\mathbf{\%}$ \\
\cline { 4 - 6 } and above & 5 & 1.2 & Literate & 4 & 0.9 \\
Unanswered & 0 & 0 & Primary education & 69 & 16.0 \\
Total & $\mathbf{4 3 2}$ & $\mathbf{1 0 0}$ & High school & 146 & 33.8 \\
\hline Gender & $\mathbf{n}$ & $\mathbf{\%}$ & College & 59 & 13.7 \\
\hline Male & 357 & 82.6 & University & 149 & 34.5 \\
Female & 71 & 16.4 & Graduate & 5 & 1.2 \\
Unanswered & 4 & 1.0 & Total & $\mathbf{4 3 2}$ & $\mathbf{1 0 0}$ \\
\cline { 4 - 6 } Total & $\mathbf{4 3 2}$ & $\mathbf{1 0 0}$ & Total working time (year) & $\mathbf{n}$ & $\mathbf{\%}$ \\
\hline Marital status & $\mathbf{n}$ & $\mathbf{\%}$ & $0-5$ & 185 & 42.8 \\
\hline Married & 304 & 70.4 & $6-10$ & 143 & 33.1 \\
Single & 119 & 27.5 & $11-20$ & 58 & 13.4 \\
Other & 1 & 0.2 & 21 and above & 11 & 2.5 \\
Unanswered & 8 & 1.9 & Unanswered & 35 & 8.1 \\
Total & $\mathbf{4 3 2}$ & $\mathbf{1 0 0}$ & Total & $\mathbf{4 3 2}$ & $\mathbf{1 0 0}$ \\
\hline & & & & &
\end{tabular}


As Table 1 was examined, it was shown that $25.7 \%$ of participants were between 30 and 34 years of age, $82.6 \%$ were male, and $70.4 \%$ were married. Moreover, it was determined that approximately half of the participants were college and higher educational status, $43.8 \%$ were employee, and $42.8 \%$ had a working time of $0-5$ year.

\section{Investigation of PA systems in terms of some variables}

In this part, it was investigated whether PA system factors (the purpose of PA, the criteria of PA, PA interviews, PA applications, the productivity effect of PA, the motivation effect of PA) applied in the forest products industry vary depending on sector, age, gender, marital status, education level, position and the total working time or not.

\section{Investigation of the PA system in terms of sector}

The difference situation in terms of the sectors of PA system factors was tested with one way analysis of variance and the results were given in Table 2 .

Table 2: The difference situation of PA system factors in terms of the sectors

\begin{tabular}{|c|c|c|c|c|c|}
\hline Subgroups of the PA & Sectors & $\mathbf{N}$ & Average & $\mathbf{F}$ & $\mathbf{p}$ \\
\hline \multirow{3}{*}{ The purpose of PA } & $\begin{array}{c}\text { Paper and paper } \\
\text { products }\end{array}$ & 25 & 3.60 & \multirow{3}{*}{0.582} & \multirow{3}{*}{0.559} \\
\hline & Panel products & 190 & 3.74 & & \\
\hline & Furniture & 217 & 3.68 & & \\
\hline \multirow{3}{*}{ The criteria of $\mathbf{P A}$} & $\begin{array}{l}\text { Paper and paper } \\
\text { products }\end{array}$ & 25 & 3.42 & \multirow{3}{*}{2.092} & \multirow{3}{*}{0.125} \\
\hline & Panel products & 190 & 3,46 & & \\
\hline & Furniture & 217 & 3.61 & & \\
\hline \multirow{3}{*}{ PA interviews } & $\begin{array}{l}\text { Paper and paper } \\
\text { products }\end{array}$ & 25 & 3.44 & \multirow{3}{*}{2.664} & \multirow{3}{*}{0.071} \\
\hline & Panel products & 190 & 3.53 & & \\
\hline & Furniture & 217 & 3.71 & & \\
\hline \multirow{3}{*}{ PA applications } & $\begin{array}{l}\text { Paper and paper } \\
\text { products }\end{array}$ & 25 & 3.34 & \multirow{3}{*}{1.708} & \multirow{3}{*}{0,182} \\
\hline & Panel products & 190 & 3.15 & & \\
\hline & Furniture & 217 & 3.32 & & \\
\hline \multirow{3}{*}{$\begin{array}{c}\text { The productivity } \\
\text { effect of PA }\end{array}$} & $\begin{array}{l}\text { Paper and paper } \\
\text { products }\end{array}$ & 25 & 3.89 & \multirow{3}{*}{1.411} & \multirow{3}{*}{0.245} \\
\hline & Panel products & 190 & 4.03 & & \\
\hline & Furniture & 217 & 4.10 & & \\
\hline \multirow{3}{*}{$\begin{array}{c}\text { The motivation effect } \\
\text { of PA }\end{array}$} & $\begin{array}{l}\text { Paper and paper } \\
\text { products }\end{array}$ & 25 & 3.73 & \multirow{3}{*}{1.437} & \multirow{3}{*}{0.239} \\
\hline & Panel products & 190 & 3.85 & & \\
\hline & Furniture & 217 & 3.95 & & \\
\hline
\end{tabular}

As a result of the analysis of variance carried out on the basis of forest products industry sub-sectors, a significant difference was not observed in terms of all the factors $(\mathrm{p}<0.05)$. According to this result, it is concluded that all sub-sectors of forest products industry exhibit a similar PA approach.
Moreover, when sector averages were examined, it was seen that paper and paper products industry was the sector that has the lowest average in terms of all the factors (excluding PA applications). On the other hand, the furniture industry had a higher average compared to other sectors. 
Investigation of the PA system in terms of age groups

The difference situation in terms of age groups of participants of PA system factors was analyzed with the analysis of variance and the results were given in Table 3 .

Table 3: The difference situation of PA system factors in terms of participant age groups

\begin{tabular}{|c|c|c|c|c|c|}
\hline $\begin{array}{c}\text { Subgroups of the } \\
\text { PA }\end{array}$ & Age groups & $\mathbf{N}$ & Average & $\mathbf{F}$ & $\mathbf{p}$ \\
\hline \multirow{5}{*}{ The purpose of PA } & 24 and below & 53 & 3.74 & \multirow{5}{*}{0.371} & \multirow{5}{*}{0.829} \\
\hline & $25-29$ & 103 & 3.71 & & \\
\hline & $30-34$ & 111 & 3.71 & & \\
\hline & $35-39$ & 93 & 3.74 & & \\
\hline & 40 and above & 72 & 3.60 & & \\
\hline \multirow{5}{*}{ The criteria of PA } & 24 and below & 53 & 3.58 & \multirow{5}{*}{1.216} & \multirow{5}{*}{0.303} \\
\hline & $25-29$ & 103 & 3.65 & & \\
\hline & $30-34$ & 111 & 3.54 & & \\
\hline & $35-39$ & 93 & 3.46 & & \\
\hline & 40 and above & 72 & 3.41 & & \\
\hline \multirow{5}{*}{ PA interviews } & 24 and below & 53 & 3,69 & \multirow{5}{*}{1.605} & \multirow{5}{*}{0.172} \\
\hline & $25-29$ & 103 & 3.74 & & \\
\hline & $30-34$ & 111 & 3.59 & & \\
\hline & $35-39$ & 93 & 3.64 & & \\
\hline & 40 and above & 72 & 3.41 & & \\
\hline \multirow{5}{*}{ PA applications } & 24 and below & 53 & 3.30 & \multirow{5}{*}{1.143} & \multirow{5}{*}{0.336} \\
\hline & $25-29$ & 103 & 3.39 & & \\
\hline & $30-34$ & 111 & 3.16 & & \\
\hline & $35-39$ & 93 & 3.14 & & \\
\hline & 40 and above & 72 & 3.25 & & \\
\hline \multirow{5}{*}{$\begin{array}{c}\text { The productivity } \\
\text { effect of PA }\end{array}$} & 24 and below & 53 & 3.95 & \multirow{5}{*}{1.504} & \multirow{5}{*}{0.200} \\
\hline & $25-29$ & 103 & 4.13 & & \\
\hline & $30-34$ & 111 & 4.11 & & \\
\hline & $35-39$ & 93 & 4.04 & & \\
\hline & 40 and above & 72 & 3.93 & & \\
\hline \multirow{5}{*}{$\begin{array}{l}\text { The motivation } \\
\text { effect of PA }\end{array}$} & 24 and below & 53 & 3.91 & \multirow{5}{*}{0.664} & \multirow{5}{*}{0.617} \\
\hline & $25-29$ & 103 & 3.98 & & \\
\hline & $30-34$ & 111 & 3.91 & & \\
\hline & $35-39$ & 93 & 3.81 & & \\
\hline & 40 and above & 72 & 3.83 & & \\
\hline
\end{tabular}

As a result of the analysis of variance carried out on the basis of age groups of forest products industry employees, a significant difference was not observed in terms of all the factors $(\mathrm{p}<0.05)$. According to this result, it is concluded that PA approaches in forest products industry does not differ in terms of age groups.

When the averages of age groups were examined, it was determined that 40 years and older participants showed a lower participation for PA approaches. On the other hand, the furniture industry had a higher average value compared to other sectors. The highest participation was provided in the age group of 25-29.

\section{Investigation of the PA system in terms of educational status}

The difference situation in terms of the 
educational status of participants of PA system factors has been tested with one-way analysis of variance and the results were given in Table 4.

Table 4: The difference situation in terms of participant educational status of factors

\begin{tabular}{|c|c|c|c|c|c|}
\hline Subgroups of the PA & Educational status & $\mathbf{N}$ & Average & $\mathbf{F}$ & p \\
\hline \multirow{4}{*}{ The purpose of PA } & Primary education & 73 & 3.47 & \multirow{4}{*}{3.218} & \multirow{4}{*}{0.023} \\
\hline & High school & 146 & 3.82 & & \\
\hline & College & 59 & 3.72 & & \\
\hline & University & 154 & 3.69 & & \\
\hline \multirow{4}{*}{ The criteria of $\mathbf{P A}$} & Primary education & 73 & 3.35 & \multirow{4}{*}{5.294} & \multirow{4}{*}{0.001} \\
\hline & High school & 146 & 3.73 & & \\
\hline & College & 59 & 3.52 & & \\
\hline & University & 154 & 3.43 & & \\
\hline \multirow{4}{*}{ PA interviews } & Primary education & 73 & 3.33 & \multirow{4}{*}{3.830} & \multirow{4}{*}{0.010} \\
\hline & High school & 146 & 3.73 & & \\
\hline & College & 59 & 3.73 & & \\
\hline & University & 154 & 3.61 & & \\
\hline \multirow{4}{*}{ PA applications } & Primary education & 73 & 3.23 & \multirow{4}{*}{6.986} & \multirow{4}{*}{0.001} \\
\hline & High school & 146 & 3.51 & & \\
\hline & College & 59 & 3.20 & & \\
\hline & University & 154 & 3.01 & & \\
\hline \multirow{4}{*}{$\begin{array}{c}\text { The productivity } \\
\text { effect of PA }\end{array}$} & Primary education & 73 & 3.96 & \multirow{4}{*}{0.838} & \multirow{4}{*}{0.474} \\
\hline & High school & 146 & 4.00 & & \\
\hline & College & 59 & 4.08 & & \\
\hline & University & 154 & 4.09 & & \\
\hline \multirow{4}{*}{$\begin{array}{l}\text { The motivation } \\
\text { effect of PA }\end{array}$} & Primary education & 73 & 3.74 & \multirow{4}{*}{1.191} & \multirow{4}{*}{0.313} \\
\hline & High school & 146 & 3.92 & & \\
\hline & College & 59 & 3.86 & & \\
\hline & University & 154 & 3.95 & & \\
\hline
\end{tabular}

As a result of the analysis of variance carried out on the basis of educational status of forest products industry employees, a significant difference in terms of all the factors except for productivity effect and motivation effect of the PA were determined $(\mathrm{p}<0.05)$.

According to this result, primary school graduates in terms of the purpose of the PA, the criteria of PA and PA interviews factors were separated from the other groups with the lowest participation rate. With regard to the PA applications, university graduates exhibited a different approach from other groups with the lowest participation rate.

\section{Investigation of the PA system in terms of gender}

The difference situation in terms of the gender of participants of PA system factors was analyzed with t-test and the obtained results were given in Table 5 .

Table 5: The difference situation of PA system factors in terms of participant gender

\begin{tabular}{cccccc}
\hline Subgroups of the PA & Gender & $\mathbf{N}$ & Average & F & p \\
\hline \multirow{2}{*}{ The purpose of PA } & Male & 357 & 3.74 & \multirow{2}{*}{0.001} & \multirow{2}{*}{0.042} \\
& Female & 71 & 3.53 & & \\
\hline \multirow{2}{*}{ The criteria of PA } & Male & 357 & 3.57 & \multirow{2}{*}{0.003} & \multirow{2}{*}{0.008} \\
& Female & 71 & 3.30 & & \\
\hline
\end{tabular}


Table 5. (continued)

\begin{tabular}{|c|c|c|c|c|c|}
\hline \multirow{2}{*}{ PA interviews } & Male & 357 & 3.66 & \multirow{2}{*}{2.781} & \multirow{2}{*}{0.019} \\
\hline & Female & 71 & 3.39 & & \\
\hline \multirow{2}{*}{ PA applications } & Male & 357 & 3.27 & \multirow{2}{*}{1.993} & \multirow{2}{*}{0.090} \\
\hline & Female & 71 & 3.06 & & \\
\hline \multirow{2}{*}{$\begin{array}{c}\text { The productivity } \\
\text { effect of PA }\end{array}$} & Male & 357 & 4.06 & \multirow{2}{*}{0.542} & \multirow{2}{*}{0.523} \\
\hline & Female & 71 & 4.01 & & \\
\hline \multirow{2}{*}{$\begin{array}{c}\text { The motivation effect } \\
\text { of PA }\end{array}$} & Male & 357 & 3.91 & \multirow{2}{*}{0.063} & \multirow{2}{*}{0.222} \\
\hline & Female & 71 & 3.78 & & \\
\hline
\end{tabular}

As a result of t-test carried out on the basis of gender of forest products industry employees, a significant difference in terms of the purpose of PA, the criteria of PA, PA interviews factors were determined $(p<0.05)$.

It was seen that female showed a lower participation than male to these subgroups. Furthermore, similar averages were obtained for other subgroups. However, there was no statistically a significant difference.

\section{Investigation of the PA system in terms of marital status}

The difference situation in terms of the marital status of participants of PA system factors has been analyzed with t-test and the results were given in Table 6 .

Table 6: The difference situation of PA system factors in terms of participant marital status

\begin{tabular}{|c|c|c|c|c|c|}
\hline Subgroups of the PA & Marital status & $\mathbf{N}$ & Average & $\mathbf{F}$ & p \\
\hline \multirow{2}{*}{ The purpose of PA } & Married & 304 & 3.69 & \multirow{2}{*}{1.865} & \multirow{2}{*}{0.478} \\
\hline & Single & 119 & 3.74 & & \\
\hline \multirow{2}{*}{ The criteria of $\mathbf{P A}$} & Married & 304 & 3.54 & \multirow{2}{*}{0.605} & \multirow{2}{*}{0.943} \\
\hline & Single & 119 & 3.53 & & \\
\hline \multirow{2}{*}{ PA interviews } & Married & 304 & 3.61 & \multirow{2}{*}{7.101} & \multirow{2}{*}{0.523} \\
\hline & Single & 119 & 3.66 & & \\
\hline \multirow{2}{*}{ PA applications } & Married & 304 & 3.22 & \multirow{2}{*}{1.350} & \multirow{2}{*}{0.737} \\
\hline & Single & 119 & 3.25 & & \\
\hline \multirow{2}{*}{$\begin{array}{l}\text { The productivity effect } \\
\text { of PA }\end{array}$} & Married & 304 & 4.08 & \multirow{2}{*}{0.127} & \multirow{2}{*}{0.090} \\
\hline & Single & 119 & 3.96 & & \\
\hline \multirow{2}{*}{$\begin{array}{c}\text { The motivation effect } \\
\text { of PA }\end{array}$} & Married & 304 & 3.94 & \multirow{2}{*}{0.182} & \multirow{2}{*}{0.030} \\
\hline & Single & 119 & 3.76 & & \\
\hline
\end{tabular}

As a result of t-test carried out on the basis of marital status of forest products industry employees, only a significant difference in terms of the motivation effect of PA were determined $(\mathrm{p}<0,05)$.

According this result, it is possible to say that married employees showed a higher participation regarding the motivation effect of PA. On the other hand, statistically significant differences did not appear in terms of other sub-groups.

\section{Investigation of the PA system in terms of position}

The difference situation in terms of the position of participants of PA system factors were tested the analysis of variance and the results were given in Table 7 . 
Table 7: The difference situation of PA system factors in terms of participant position

\begin{tabular}{|c|c|c|c|c|c|}
\hline Subgroups of the PA & Position & $\mathbf{N}$ & Average & $\mathbf{F}$ & p \\
\hline \multirow{3}{*}{ The purpose of PA } & Senior & 38 & 3.76 & \multirow{3}{*}{0.281} & \multirow{3}{*}{0.755} \\
\hline & Middle-level & 175 & 3.68 & & \\
\hline & Employee & 189 & 3.65 & & \\
\hline \multirow{3}{*}{ The criteria of PA } & Senior & 38 & 3.63 & \multirow{3}{*}{0.569} & \multirow{3}{*}{0.567} \\
\hline & Middle-level & 175 & 3.49 & & \\
\hline & Employee & 189 & 3.47 & & \\
\hline \multirow{3}{*}{ PA interviews } & Senior & 38 & 3.75 & \multirow{3}{*}{1.575} & \multirow{3}{*}{0.208} \\
\hline & Middle-level & 175 & 3.63 & & \\
\hline & Employee & 189 & 3.51 & & \\
\hline \multirow{3}{*}{ PA applications } & Senior & 38 & 3.38 & \multirow{3}{*}{3.186} & \multirow{3}{*}{0.042} \\
\hline & Middle-level & 175 & 3.06 & & \\
\hline & Employee & 189 & 3.28 & & \\
\hline \multirow{3}{*}{$\begin{array}{c}\text { The productivity } \\
\text { effect of PA }\end{array}$} & Senior & 38 & 4.07 & \multirow{3}{*}{0.092} & \multirow{3}{*}{0.912} \\
\hline & Middle-level & 175 & 4.03 & & \\
\hline & Employee & 189 & 4.05 & & \\
\hline \multirow{3}{*}{$\begin{array}{c}\text { The motivation effect } \\
\text { of PA }\end{array}$} & Senior & 38 & 3.98 & \multirow{3}{*}{1.205} & \multirow{3}{*}{0.301} \\
\hline & Middle-level & 175 & 3.93 & & \\
\hline & Employee & 189 & 3.82 & & \\
\hline
\end{tabular}

As a result of the analysis of variance carried out on the basis of position of forest products industry employees, only a significant difference in terms of $\mathrm{PA}$ applications were observed $(\mathrm{p}<0.05)$.

According to this result, it was understood that middle-level employees showed the lowest participation into PA applications. Statistically significant differences did not appear in terms of other sub-groups.

Investigation of the PA system in terms of total working time

The difference situation in terms of the total working time of participants of PA system factors has been tested with one way analysis of variance and the results were given in Table 8.

Table 8: The difference situation PA system factors in terms of participant working time

\begin{tabular}{cccccc}
\hline Subgroups of the PA & Working time & $\mathbf{N}$ & Average & $\mathbf{F}$ & $\mathbf{p}$ \\
\hline \multirow{4}{*}{ The purpose of PA } & $0-5$ & 185 & 3.59 & & \\
& $6-10$ & 143 & 3.69 & \multirow{2}{*}{2.192} & \multirow{2}{*}{0.088} \\
& $11-20$ & 58 & 3.80 & & \\
\hline \multirow{4}{*}{ The criteria of PA } & 21 and above & 11 & 4.09 & & \\
& $0-5$ & 185 & 3.44 & & \\
& $6-10$ & 143 & 3.54 & \multirow{2}{*}{0.844} & \multirow{2}{*}{0.471} \\
& $11-20$ & 58 & 3.54 & & \\
PA interviews & 21 and above & 11 & 3.73 & & \\
& $0-5$ & 185 & 3.52 & & \\
& $6-10$ & 143 & 3.65 & \multirow{2}{*}{0.794} & 0.498 \\
\hline \multirow{2}{*}{ PA applications } & $11-20$ & 58 & 3.61 & & \\
& 21 and above & 11 & 3.83 & & \multirow{2}{*}{0.002} \\
\hline
\end{tabular}


Tablo 8. (continued)

\begin{tabular}{cccccc}
\hline & $11-20$ & 58 & 3.43 & & \\
& 21 and above & 11 & 3.72 & & \\
\hline & $0-5$ & 185 & 4.05 & & \\
The productivity & $6-10$ & 143 & 3.98 & 1.685 & 0.170 \\
effect of PA & $11-20$ & 58 & 4.08 & & \\
& 21 and above & 11 & 4.43 & & \\
The motivation effect & $0-5$ & 185 & 3.95 & & \\
of PA & $6-10$ & 143 & 3.81 & 0.843 & 0.471 \\
& $11-20$ & 58 & 3.86 & & \\
\hline
\end{tabular}

As a result of the analysis of variance carried out on the basis of total working time of forest products industry employees, a significant difference in terms of PA applications were observed $(\mathrm{p}<0.05)$.

According to this result, the participants that have 21 years and over working time provided a higher level of participation regarding the PA applications. A statistically significant difference in terms of working time regarding other PA subgroups has not been determined. However, when Table 8 was analyzed, it was observed that the level of participation increased depending on the increased working time for all groups.

\section{Discussion and Conclusion}

In the present study, the evaluation by employees of PA system applied in the forest products industry was aimed. In addition, differences in appraisals based on the subsectors and demographic characteristics were investigated. Accordingly, the following conclusions were drawn from this study:

As a result of validity and reliability analyses of the questionnaire implemented, the questionnaire was reduced to 33 from 51 judgments. With this operation, structure validity of the scale was achieved (\% 59.942).

It was detected that $25.7 \%$ of participants were between 30 and 34 years of age, $82.6 \%$ were male, $70,4 \%$ were married, nearly $50 \%$ were college or higher education level, $43.8 \%$ were employee, and $42.8 \%$ had a total working time of $0-5$ year.

It was detected that PA systems do not differ statistically on the basis of forest products sub-sectors. This result means that PA applications applied in all sub-sectors are perceived in a similar manner in terms of employees.

Statistically significant differences did not occur in terms of age groups of the participants in the perception of the PA systems. This result shows that PA applications are perceived at the same level in terms of age groups.

A difference on basis of educational status in the perception of the PA systems was determined. Primary school graduates were separated from the other groups with the lowest participation rate in terms of the purpose of the PA, the criteria of the PA and PA interviews. The university graduates had a different approach from other groups with the lowest participation rate in terms of PA applications. According to these results, it is possible to say that the reasons and goals of making the PA cannot be explained completely to primary school graduates. Moreover, it was concluded that university graduates observed shortcomings at the point of PA applications.

It was seen that there were significant differences in terms of gender in the perception of the PA systems. In this context, it was detected that female showed a lower participation to the subgroups of the PA compared to male. According to these results, it was concluded that female were not satisfied with the PA applications.

A significant difference on basis of marital status in the perception of the PA systems was determined. The married employees showed a higher rate of 
participation with regard to the motivation effect of PA.

A significant difference depending on the position in the perception of the PA systems studied was determined. In this regard, middle-level employees showed the lowest participation to the judgments about PA applications. According to this result, it is possible to say that middle-level employees as PA practitioners see their work unsatisfactory.

Based on the total working time, significant differences were identified in the perception of the PA systems. It was determined that the participants with 21 years and over working time provided a higher level of participation to the judgments about the PA applications. According to this result, the experienced employees consider that PA applications have sufficient qualifications.

\section{Acknowledgement}

This research was supported by the Scientific Research Projects Fund of Karadeniz Technical University, Trabzon Turkey; Project no. 9760.

\section{References}

Akçakanat, T. (2009). Performance evaluation in human resources management: an application in Isparta provincial security directorate, MS Thesis, SDU Institute of Social Sciences, Isparta, Turkey

Ataay İ.D., (1990). Business valuation and success valuation methods.: Faculty of Business Administration: 235, İstanbul

Chenhall R.H. (2005). Integrative strategic performance measurement systems, strategic alignment of manufacturing, learning and strategic outcomes: An exploratory study. Accounting, Organizations and Society, 30, 395-422.

Dewettinck K. \& van Dijk H. (2013). Linking Belgian employee performance management system characteristics with performance management system effectiveness: exploring the mediating role of fairness. The International Journal of Human Resource Management, 24(4), 806-825.

Ferreira A. \& Otley D. (2009). The design and use of performance management systems: An extended framework for analysis. Management Accounting Research, 20, 263-282.

Kalayc1 Ş., (2009). SPSS applied multivariate statistical techniques. Asil Publishing, Ankara, Turkey.

Kumbhar S.A. (2011). Impact of performance appraisal on corporate profitability. Indian Streams Research Journal, DOI : 10.9780/22307850.

Mishra G. \& Farooqi R. (2013). Exploring employee satisfaction with performance management and the challenges faced in context of IT industry. Compensation \& Benefits Review, 45(6), 329-339.

Pirttimäki V., Lönnqvist A., Karjaluoto A. (2006). Measurement of business intelligence in a Finish telecommunications company. Electronic Journal of Knowledge Management, 4, 83-90.

Serin H., Şahin Y., Durgun M. (2014). Furniture sector of turkey, European Journal of Research on Education, Contemporary Studies in Social Sciences III, 2 (6), 149-153.

Serin H. \& Şahin Y., (2016). Determination of contact level between top management sub-departments at furniture enterprises. International Furniture Congress, 461466.

Sharma S. (1996). Applied Multivariate Techniques, John Wiley\& Sons Inc., Newyork.

Şahin Y. \& Serin H., (2016). A reseach on particle board factory by utilization of integer linear programming. International Forestry Symposium, 785-789.

Tarlı̆ Y.T., (2006). A study to determine the attitude towards the performance evaluation process and the areas where the performance evaluation results are used. MS Thesis, YTÜ Institute of Social Sciences, İstanbul, Turkey.

Yilmaz E.F., (2006). The impact of the performance appraisal system on business productivity and a sample application. MS Thesis, Institute of Social Sciences of Trakya University, Edirne, Turkey 